UDC 657.1

JEL Classification: D800; M400

DOI: https://doi.org/10.35774/visnyk2020.04.197

\title{
Viktoriya ROZHELYUK,
}

Ds (Economics), Professor of Accounting and Taxation Department,

West Ukrainian National University,

11 Lvivska street, Ternopil city, 46000, Ukraine,

e-mail: rozelyk@ukr.net

ORCID ID: 0000-0002-2298-6160

Vita SEMANIUK,

Ds (Economics), Associate Professor of Financial

Control and Audit Department,

West Ukrainian National University,

e-mail: V.Semaniuk@tneu.edu.ua

ORCID ID: 0000-0001-7010-9923

\section{PHILOSOPHICAL APPROACHES TO UNDERSTANDING ACCOUNTING INFORMATION IN A POST-INDUSTRIAL SOCIETY}

Rozhelyuk V., Semaniuk V. Filosofski pidxody do rozuminnya oblikovoyi informaciyi u postindustrialnomu suspilstvi [Philosophical approaches to understanding accounting information in a post-industrial society]. The Herald of Ternopil National Economic University. 2020. Vol. 4. P. 197-209. DOI: https://doi.org/10.35774/visnyk2020.04.197

Рожелюк В., Семанюк В. Філософрські підходи до розуміння облікової інформації у постіндустріальному суспільстві. Вісник Тернопільського національного економічного університету. 2020. Вип. 4. C.197-209. DOI: https://doi.org/10.35774/visnyk2020.04.197

\section{Abstract}

Introduction. Post-industrial society is characterized by new requirements for economic information provided by the accounting system. The transformation of the understanding of the essence of economic information in modern conditions is associated with a number of important factors. Therefore, the study of these factors, as well as the corresponding changes in the characteristics and perception of economic information is an important area of research.

Objective. The purpose of the article is to substantiate the approaches to the interpretation of information as a process of programmatic generation of reality in terms of information modelling of economic and social phenomena.

Methods. The following approaches are used for this purpose: entropic, algorithmic, combinatorial, which provide quantitative determination of the complexity of the displayed object, process or phenomenon; syntactic, which indicates the internal features of the processes that are displayed, their structure, organization, complexity, etc; semantic, which

(C) Viktoriya Rozhelyuk, Vita Semaniuk, 2020. 
allows us to describe the content and novelty of information for the user; pragmatic, which allows us to assess the usefulness of the received message.

Results. The concept of "information" has been researched as a basic element of accounting science in post-industrial society, which involves understanding the role of thought processes in cognition of economic reality and the creation of information matrices to form models of behaviour of objects / subjects of economic activity. It was determined that information is interconnected with human, consciousness, thinking and perception of reality through the prism of economics, and economic interpretation of information involves understanding the categories of value of information, such as resources, goods, objects of labour and more. Accounting information is considered as a reflection of the content of relations that arise in the process of economic agent and its adaptation to the external environment, regardless of the form of presentation of this information. Emphasis is placed on the philosophical interpretation of information as a process of programmatic generation of reality in terms of information modelling of economic and social phenomena. We have proved that the main value of accounting information is its usefulness for a particular management decision, and the use of accounting information, taking into account its value for management is limited by up perception and reflection of users of this information.

Discussion. A promising area of further research is the identification of opportunities for the formation of different types of information for interested users and the development of appropriate methods for processing credentials to implement in practice the task of maximizing the satisfaction of their information requests.

Keywords: information, information society, accounting information, knowledge, accounting theory.

Formulas: 0; fig.: 0; tabl.: 0; bibl.: 25.

\section{Вікторія РОЖЕЛЮК,}

доктор економічних наук,

професор кафедри обліку і оподаткування,

Західноукраїнський національний університет,

вул. Львівська, 11, м. Тернопіль, 46009, Україна,

e-mail: rozelyk@ukr.net;

ORCID ID: 0000-0002-2298-6160

\section{Віта СЕМАНЮК,}

доктор економічних наук, доцент кафедри фрінансового контролю та аудиту,

Західноукраїнський національний університет,

вул. Львівська, 11, м. Тернопіль, 46009, Україна,

e-mail: V.Semaniuk@tneu.edu.ua

ORCID ID: 0000-0001-7010-9923

\section{ФІЛОСОФСЬКІ ПІДХОДИ ДО РОЗУМІННЯ ОБЛІКОВОЇ ІНФОРМАЦІЇ У ПОСТІНДУСТРІАЛЬНОМУ СУСПІЛЬСТВІ}

\section{Анотація}

Вступ. Постіндустріальне суспільство характеризується новими вимогами до економічної інформації, яку надає система бухгалтерського обліку. Трансформація розуміння сутності економічної інформації в сучасних умовах пов'язана з низкою 
важливих чинників. Тому дослідження цих чинників, а також відповідних змін характеристик і сприйняття економічної інформації $\epsilon$ актуальним напрямом наукових досліджень.

Mета. Мета дослідження полягає в обгрунтуванні підходів до трактування інфрормації як процесу програмного породження дійсності з точки зору інфрормаційного моделювання економічних та соціальних явищ.

Методи дослідження. Для встановлення й ідентифрікації сутності інформації в умовах постіндустріального суспільства використано такі методи: ентропійний, алгоритмічний, комбінаторний, які забезпечують кількісне визначення складності відображуваного об'єкта, процесу чи явища; синтаксичний, що вказує на внутрішні особливості процесів, що відображаються, їхню структуру, організацію, складність тощо; семантичний, що дає змогу описати зміст та новизну інформації для користувача; прагматичний, що дозволяє оцінити корисність отриманого повідомлення.

Результати. Досліджено поняття «інформація» як базовий елемент облікової науки в постіндустріальному суспільстві, яке передбачає розуміння ролі мисленнєвих процесів у пізнанні економічної реальності та створенні інформаційних матриць 3 метою формування на їі основі моделей поведінки об'єктів / суб'єктів економічної діяльності. Визначено, що крізь призму економіки інфрормація взаємопов'язана з людиною, свідомістю, мисленням і сприйняттям дійсності, а економічна інтерпретація інформації передбачає розуміння категорій вартості інформації як ресурсу, товару, предмета праці тощо. Розглянуто облікову інфоормацію як відображення змісту відносин, що виникають у процесі діяльності економічного агента та його адаптації до зовнішнього середовища, незалежно від фрорми представлення цієї інфрормації. Акцентовано увагу на фрілософрській інтерпретації інформації як процесу програмної генерації реальності з точки зору інформаційного моделювання економічних та соціальних явищ. Доведено, що основу цінності облікової інформації становить їі корисність для конкретного управлінського рішення, а використання облікової інформації з урахуванням ї̈ цінності для управління обмежене апперцепцією та рефлексією користувачів цієї інформації.

Перспективи. Перспективним напрямом подальших досліджень є ідентифрікація можливостей фрормування різних видів інформації для зацікавлених користувачів і розробка відповідних методик опрацювання облікових даних для реалізації в практичній площині завдання максимального задоволення їхніх інформаційних запитів.

Ключові слова: інфрормація, інфрормачійне суспільство, облікова інформація, знання, теорія обліку.

Формули: 0, рис.: 0, табл.: 0, бібл.: 25.

Problem formulation. Economic development is a reality based on the historical scale of time, has categorical features, conceptual apparatus, established scientific schools. At the present stage, information factor of socio-economic development acquires global significance, which allows us to state the phenomenon of information revolution as a result of two parallel processes - the constant growth of the role and amount of information needed 
for society, and the process of technology improvement. As a result, the information sphere was transformed into a priority sector of society. With the transition to the information society, companies have to pay more attention to the process of obtaining (generating) information and transforming it into knowledge. It is the ability of the enterprise to perceive, accumulate and store information that determines its potential for its transformation into an array of knowledge of the enterprise. The information society creates a demand for new knowledge, intellectualizes society and stimulates creativity. The new millennium is characterized by the expansion of the information space, which covers all areas of human existence, defining its values. With the emergence of the information society, in which information is the essence and form, the real value, the innovative moods of people grow, which, in turn, requires a new quality of thinking.

It is worth noting that scientists, tried to predict the further stages of development of society long before our days, and even then the advent of the information age was obvious. Thus, in the 20s of the twentieth century O. Spengler expressed a premonition of the inevitability of a sharp turn in the history of mankind, associated with the increasing role of information. In the 1940s, the Australian economist C. Clark was already talking quite clearly about the beginning of a period of information and service society with a new economy and technology. In the late 50's, the American economist F. Mahlup put forward the thesis of the advent of the information economy and the transformation of information into an important commodity, and in the late 1960s, the leader of post-industrialism D. Bell already predicted the transformation of industrial society into information one [1].

At the present stage, information products and services are becoming a strategic resource for economic development. The role of information is especially important in the financial business, where decision-making is based on timely and reliable information, which determines the high efficiency of such a decision, and can sometimes cause significant losses. According to experts, a well-executed information product retains its value longer than specific media, and the cost of an information product is constantly growing due to the need for highly skilled labor of its producers, who in the business system are, in fact, accountants. The main principle of the new paradigm of the information society is the focus on intellectual and creative potential.

The global information society is a society of mental labor, which is based on the use of knowledge in all spheres of human activity - production, science, education. Note that there are fundamental contradictions between the principles of accounting and the properties of the information economy (or algebraic properties of knowledge). Accounting is based on the principles of ordinary arithmetic - if there was an income, there should be the same outcome. Knowledge is a subject to completely different algebraic rules, they have no property of rarity, they act as multipliers of the value of goods [2]. The modern information paradigm of human development gives the process of cognition a number of essential features and trends, one of which is associated with new information processes that require understanding at the general theoretical and specific scientific level.

Analysis of research and problem statement. Information has become the object of study by A. Berg, I. Bongart, L. Brillouin, N. Winner, V. Glushkov, A. Kolmogorov, V. Korogodin, A. Lyapunov, J. von Neumann, G. Paska, I. Prigogine, A. Turing, K. Shannon, J. Schreider, A. Ursul, W. Ashby, D. Chernavsky, K. Colin and others to some extent. Over 
the last decade, K. Shannon and W. Ashby have identified a number of problems in the development of its phenomenon and the phenomenon of the information society in the concepts of limiting information only in a quantitative aspect. The scientific and technological revolution and the development of new technologies was caused by evolution of information technology and its introduction into all spheres of life. There have been changes in the processing, transmission and storage of information, and an information revolution is taking place now due to the rapid spread of PCs. This point of view was held by D. Bell, and all supporters of the theory of post-industrialism. It is difficult to deny here that the only remark concerns the scientific community of accountants who are not yet aware of the importance of this concept and its impact on their immediate object of study - the accounting system.

Setting objectives. The purpose of the article is to substantiate the approaches to the interpretation of information as a process of programmatic generation of reality in terms of information modelling of economic and social phenomena.

Presentation of the main material of the study. In the information economy, the production, dissemination and use of knowledge become a major factor in economic development, a guarantee of social stability and a condition for achieving a high level of employment. All sectors of such an economy are knowledge-intensive, whether they use high technology or not. Shevchuk O. B. [3] considers information capital, which is "a meaningful form in which organically accumulated and converted economic, human, cultural and social capital formed during the second half of XX century under the influence of the 19th information technology revolution." as the core of the information (post-industrial) economy. The author considers it as a dominant factor of production in the information society, which is the cornerstone of a new, information economy. In many cases, we understand information intuitively and give it a different content: "information", "data", "signal", "knowledge", "content" - all these definitions are synonymous and do not explain each other, but they can be replaced by the word information according to $\mathrm{K}$. Shannon's criteria. The word information has been known to us for a long time and rarely attracts attention. However, given the growing importance of information in human life, and in economic life in particular, we have to examine its phenomenon in detail. Problems of philosophical understanding of information were studied by British professor Luciano Floridi in 1964, who developed the concept of information as a fundamental concept of philosophy, along with such concepts as being, energy, matter, knowledge, life, etc., expressing these concepts in terms of information [4]. In other words, in the concept of L. Floridi information becomes a defining concept, only with the existence of which all other categories of philosophy can be expressed. The Latin word "Informatio" has two meanings: image, designation or explanation, interpretation. The new dictionary of the modern Ukrainian language gives us the following definition: "Information is a message about the state of affairs, the state of something" [5, p. 268]. ISO/IEC 2382-1: 1993 standard interprets information as "knowledge of facts, events, things, ideas and concepts that have a specific meaning in a given context" [6]. Modern interpretations of the information we encounter in the literature are all based on the interpretations of $\mathrm{K}$. Shannon and N. Winner. N. Winner defines information as "content obtained from the outside world in the process of our adaptation to it and the adaptation of our feelings to it" [7], and K. Shannon introduced the classical definition of information as "overcoming entropy" into scientific 
language [8]. Such interpretations of the term "information" are presented in a narrow meaning and technical interpretation. But do we have enough technical interpretation to understand information in economic life? Of course, economics, as a behavioral science, needs a deeper meaning and interpretation of information to understand its movement and processing. The existing definitions describe rather the "effect of information" instead of its nature [9, pp. 130-149].

Through the comparison of the properties of objects, V. Sanochkin [10] interprets the essence of the latter as the reason for the appearance of information, substantiating this by the fact that the comparison reduces uncertainty and thus increases the amount of information. A. Sokolov claims that "Semantic information is an ambivalent concept that defines a means of expressing content through communicative signs" [11]. The axiomatic nature of information is proved by T. Stonier, who endows it with the properties of an independent ontological category, however the substantiality of information is questioned by the determinism of information as a means of communication or exchange by matter or consciousness. This approach requires determining the nature of information and the operation of its mechanisms. The synergetic paradigm, which is established in postclassical science, studies the behavior of complex dynamical systems should consider information as a phenomenon, not just as a process of creating / generating information and its stages. This approach to the interpretation of information gives a new impetus to understanding its nature, considering information as a multifaceted and multilevel process. $\mathrm{N}$. Winner states that "Information is not matter and not energy. This is a third thing " [7]. It seems to be not scientific, but allows us to conclude that information can not be reduced to material. We can conclude that in addition to matter and energy there is another substance - information. The concepts of "matter", "energy", "information" are equivalent in terms of general scientific and philosophical categories, which complement each other and characterize various aspects of the objects, processes and phenomena of physical reality studied by science. Modern post-classical science emphasizes the importance of studying not only material (physical) but also intangible, ie informational properties of objects of reality. Such provisions prove the formation of a new scientific picture of the world, which is called not synergetic, but informational, where information interactions are the basis of the universe. In terms of accounting knowledge, despite the fact that information is the subject and product of accounting, the definition of "information" has been little studied. Shannon's information theory is applicable for solving technical and organizational aspects of accounting, but it does not take into account the semantic aspects, reflection, cost and efficiency of information use.

In the institutional aspect, the phenomenon of information was studied by F. Knight, putting into equation the efficiency of the firm and its information support. While researching transaction costs, R. Coase gave the structure of arguments for the regularity of their functioning through the concept of information. O. Williamson described information in the context of research on specific assets, making them dependent on education, knowledge and information. For the theoretical conceptualization of the concept of "information", let's consider it as a general scientific phenomenon with its properties, manifestations and patterns. To interpret the information in the ontological aspect, we turn to such philosophical concepts as "environment" and "object", which interact with each other in time and space 
(exchange of matter and energy). The interaction can be symmetrical (the amount of substance given by one object is equal to the amount received by another) and asymmetric (when from one object to another passes a certain substance and the loss of one does not coincide with the acquisition of another), which gives us reasons to determine certain properties of information. Information interaction is any interaction between objects, when one acquires a certain substance and the other does not lose it. This substance is called information that cannot exist beyond the interaction of objects and is not lost by any of them in the process of interaction.

The following main approaches are used in the study of the nature of information: attributive - defines information as a property of the motion of matter, a component of the structure, order and diversity of its states. In this approach, the presence of information is attributed to any matter, and, consequently, not only in living things, but also in all inanimate nature [12]; functional-cybernetic - considers information as "a quality of a certain class of information system, which arises and is enriched in the process of formation, development of these systems, their functional interaction between themselves and the outside world" [13]; anthropocentric approach is characterized by the statement that only human has the ability to receive, create, store, transmit information, because they can speak. Information is interpreted as data obtained by a person to reflect the facts of the material or spiritual world, which in the process of communication are transformed into knowledge.

Despite the high interest in the concept of information and its importance in all, without exception, the processes of society, a single scientific approach has not been achieved by scientists. Despite the mathematical accuracy of his theory, K. Shannon warned that it is not suitable for transfer to other sciences: "Representatives of various sciences need to understand that the main provisions of information theory relate to a very specific area of research, a direction that does not necessarily have to be fruitful in psychology, economics and other sciences "[8]. What is more, there is a plurality of sciences about information that is caused by specificity of its existence in various types of systems. Each individual science has its own definitions and therefore there are many definitions. Our task is to find an accounting interpretation of the information. Summarizing the aforementioned definitions, we see that information has many manifestations, and it manifests itself in different systems - inanimate nature, biological, technical, social, human consciousness in different ways $[14$, p. 62]. Accounting science is at the junction / interaction of these systems, so its interpretation of information differs from others, while the physical nature of the media, which is often paid attention to in the economy, does not matter.

The fundamental law of information is that it is an objective characteristic at all stages of the organization of matter as a measure of order of structures and their interaction. The basis of the development of any activity is the dialectical unity and the struggle of opposites organization and disorganization. Conducting economic activities, people organize structures that are developing and need management. The processes of interaction of varying degrees of intensity are conducted between these structures, accompanied by varying degrees of information flows.

The accounting system forms an information display of the state, properties and motion of real world systems. The interaction between structures is characterized in such dimensions as space, time, motion and reflection. With the development of the structures 
and their complication, their reflection becomes more complicated and more complete. It is the level of organization that characterizes the development of the system. In this aspect, A. Ursul interprets information as diversity. If objective information is considered to be a property of matter, then ideal, subjective information is a reflection of objective, material information [15, pp. 228-229].

In the literature, information is divided into structural and operational. Abdeev R. understands structural information as information that is contained in the object of nature, and operational information is that which is received by the recipient of information [16]. Thus, structural information is a property of organized systems that manifest themselves in the structure of reality, where ideal and physical reality are mutually reflected, creating the possibility of manifestation of various aspects of the phenomenon of information [17, pp. 56-61]. Information can be objective as a property of matter and subjective as a reflection of objective material information.

At the enterprise level, information reflects all possible processes and forms of interaction of the enterprise with other subjects through information management activities. This is the main thesis that proves the dualistic unity of information and management. Information is impossible without management. Information without management has no meaning. Structural information is contained in the object of nature, and operational is received by the recipient of information [16]. Without understanding who the user of the information is, all our efforts are useless. After all, only the user can appreciate the data about the world that the information contains.

Accounting information has a special meaning for users and is generated in an accounting system. Information in accounting is like energy in physics. It is the subject and the product of research. The accounting interpretation of the definition of "information" in most cases is intuitive, but there is no understanding of the nature of this concept. In the accounting process a person learns the economic reality by forming an information matrix, builds models of behavior on its basis and predicts the behavior of objects / subjects of economic life. Data carriers can be different: paper, electronic, conditional, etc., but information is born in the brain through the process of thinking. The exogenous nature of data processing algorithms requires a special type of thinking to generate / create it. The response to any disturbance (internal or external) leads to chaos in unbalanced dynamical systems, which are economic systems of different levels. Purposeful actions in response to disturbances and reduction of uncertainty provide recovery not of information about the system, but of the system itself as an information structure. The enterprise is a complex dynamic system and it includes both control and managed subsystems, between which there is an information connection. A control system is an information system that produces and sends information signals to a controlled subsystem. The controlled subsystem responds to the content of these signals and strives for self-organization, taking into account the influence of information signals through the feedback mechanism. We must not lose sight of the influence of the external environment, which in combination with internal factors of influence lead to the formation of a new trajectory of development of the economic entity. Human is only an element of the control system. Having experience and the knowledge system, manager gives the greatest importance to those information flows that have a significant place in his algorithm / style / method of decision making. The same 
information can cause different reactions from people with different behavioral matrices. The subjects of information relations are all participants in market interaction who exist in a single economic space. Accounting information characterizes knowledge about facts, events, processes that have a specific meaning / context. We consider the complexity of the system as a criterion for the existence of a set of information, and our understanding of accounting subsystems (managerial, financial, strategic) is based on this statement. In the accounting system predictive reflections of reality can be formed [18, pp. 20-24] as a basis for self-organization and identification of optimal development scenarios. These scenarios are aimed at achieving the goal and adaptation, thus generating knowledge about the surrounding reality, monitoring mechanisms, generalization of data by means of sign systems, the creation of information models of reality within which uncertainty is reduced. The information is decoded and gives us an information model that is used in the management process. And another argument in defense of the interpretation of accounting as a special way of thinking is that human adapt and archive all reactions to information by means of coding mechanisms of consciousness (thinking, language, sign systems), creating arrays of knowledge on which to build information models of reality.

Information is a universal probabilistic process of generating messages to adapt an open dynamic system to changes in the environment, which interacts with other systems and probable acceptable models of reality (economic), which reduces uncertainty and regulates the entropy of the system, achieving its order and development. In the theory of accounting for post-industrial society, understanding information as a process of program generation of reality is important in terms of information modeling of economic and social phenomena [19].

There is a well-known caveat that information should have three parameters: syntactic, semantic (clear and incomprehensible information) and pragmatic. It is important to consider different approaches to information in accounting theory: entropic, algorithmic, combinatorial - give a quantitative definition of the complexity of the displayed object, process or phenomenon; syntactic approach to information shows the internal features of the processes that are displayed, their structure, organization, complexity, etc.; semantic approach to information allows to describe the content and novelty of information for the user; pragmatic allows to assess the usefulness of the message [19]. If we take into account only the quantitative aspect, then among the two judgments one may not make sense, but according to Shannon's theory, they have the same amount of information. Therefore, it is necessary to take into account the conclusions of L. Floridi, who interprets information as content and knowledge. And in knowledge the semantic aspect is the main one. L. Floridi's semantic theory is more interesting for accounting science, where the main parameters are the content of information, rather than its quantity [4]. L. Floridi's semantic theory of information is based on the teachings of N. Winner and emphasizes the polysemy and ambiguity of information, and the value of information depends on the environment and context. Information is not a word, but mental activity, intellect. Cicero, using the verb informare, indicates a complex mental activity, which consists of giving something form, filling matter with meaning by giving it an active perception [20], the term information (Latin. "informatio") has two meanings: image or notation and explanation, interpretation. Once 
information was important for the company, but was not a critical element of its activities, and in modern conditions - information is the main resource of the economy.

Ursul A.D. claimed that "the possession of information and its widespread use as a major resource and priority factor in the development of civilization gives humanity hope for a way out of the systemic crisis and to solve many global problems of today, as well as new ones that await us in the future" [15].

Information theory is an intellectual metastructure, the fundamental ideas of which have penetrated deeply into the basis of all sciences and determine the view of the world that is formed within the new paradigm. Technologically, information today is seen as the very essence of society, just as genetic information is the key to biology. The basis of economic relations is also information, and life in general is a gigantic, infinitely complex and perfect process of processing information that is stored within us and transmitted from one to another [20].

Static and dynamic aspects of the study of information lead us to the conclusion about the existence of static information - the distribution of energy and matter in space and dynamic information - changes in processes in space and time. Thus, the carrier of static information in nature is matter (substance), and the carrier of dynamic energy - energy (field), which ensures the dissemination of information in space. The information that allows us to understand the change in the indicator is static. Some researchers believe that information is a function of time. As noted by L.I. Khoruzhiy [21], "accounting for the time factor is one of the difficulties in determining the information needed in the future." From the point of view of H.M. Zakharchyshyn [22, p. 12-13], the information society expands the space, but condenses time, stimulating the choice of priorities. Given this, at the micro level to assess the effectiveness of enterprises, one should not be limited to the usual components of resource potential, it is necessary to supplement it with a new resource time. Time is the most scarce resource and, unlike material resources, does not have the ability to accumulate. In the market field, the supply of time as a resource, as opposed to the supply of materials, fixed assets, human resources, is absent, and in the global dimension is limited, because time has its price.

All other resources, management decisions, innovation cycles, organization of the accounting process also depend on time. Manifestation of the category of time in the production activities of enterprises also depends on the pace, proportions and cost of time. The consolidation of time necessitates its evaluation and selection of the most effective actions, so lack of time forces managers to respond quickly to environmental challenges and choose priorities in the enterprise and focus on the most important management issues. The accounting system in the information society under the pressure of time is required to be extremely up-to-date information, which is achieved through its proper organization. Modern economic processes are characterized by almost instantaneous transmission of information about changes in industry markets, as a result of which decisions on transactions can be made in real time, and the transactions themselves are carried out very quickly and almost around the clock. In the information economy, the reproduction of economic processes is accelerating (instead of months and weeks - days or even hours) [2]. This is due to the introduction of new information technologies, the elimination of intermediate stages in the system "producer - consumer" (eg, supply of parts, equipment, etc. from 
manufacturers to assemblers, bypassing warehouses; banking, etc.). Informatization of economic processes involves their transition to fundamentally new basics - the organization and use of interconnected information flows, widespread introduction of information and telecommunications technologies, determining on this basis the accuracy, timeliness and validity of decisions made at different levels of management. In modern conditions there is a growing interest in the study of interpretations of the concept of "information" in general and "economic / accounting information" in particular. P.C. Rodriguez, F. Silveira, B.M. Santos and F. Molinar, analyzing the publications of scientific periodicals, rightly note that today the views not only on the role but also on the essence of information data have changed significantly. Not the last role in this process is played by new technologies [23, p. 1213]. The relevance of research on the impact of modern theories and problems on accounting and accounting information is also pointed out by N.V. Semenyshena, Z.-M. Zadorozhny, I. B. Sadovska and N.M. Khorunzhak, who believe that currently there is an objective need to reconsider the basic principles and concepts, in particular in the context of institutionalism, and this is significantly influenced by the interested user of information man [24, p.695; 25, p. 114].

Conclusions. Information through the prism of economics is inextricably linked with a human, consciousness, thinking and perception of reality. Economic interpretation of information involves the categories of value of information, information as a resource, commodity, object of labor and so on. Accounting information reflects the content of the relationships that arise in the process of economic agent and its adaptation to the external environment, regardless of the form of presentation of information. "Data" in the accounting system is transformed into "information", and the management system, using this information if necessary, bringing into it their experience, a certain set of values, professional and expert interpretation, acquires "knowledge". Obviously, it is necessary to change the basic paradigm of accounting and its harmonization within the new management information system, as well as the formation of special techniques that will provide the necessary information about the external environment of the enterprise. Thus, to ensure the effective operation of the enterprise, it is necessary to develop an integrated management information system, expand the subject of accounting and develop the latest methods of processing and creating information. This will ensure that the capabilities of the accounting system meet the needs of users in a post-industrial economy.

Prospects for further research. A promising area of further research is the identification of opportunities for the formation of different types of information for interested users and the development of appropriate methods for processing credentials to implement in practice the task of maximizing the satisfaction of their information requests.

\section{References}

1. Krutiyk, A. B., Muravyev, A. Y. (2001) Antikrizisnyj menedzhment [Anti-crisis management]. S.Pb.: Piter. 432 p. [in Russian].

2. Rozhelyuk, V. M. (2013) Organizaciya buxgalterskogo obliku diyalnosti pererobnyx pidpryyemstv: monografiya [Organization of accounting for the activities of processing enterprises: monograph]. Kiyiv: NNCZ IAE. 488 p. [in Ukrainian]. 
3. Shevchuk, D. A. (2009). Istoriya ekonomiki [History of economics]. Retrieved from: https://may.alleng.org/d/econ/econ173.htm [in Russian].

4. Florydy, L. (2002). What is the Philosophy of Information? Metaphilosophy. Vol. 33, 1/2, 123-145. Retrieved from: https://onlinelibrary.wiley.com/doi/epdf/10.1111/14679973.00221 [in English].

5. Radchenko, I. O., Orlova, O. M. (2007). Novyj tlumachnyj slovnyk suchasnoyi ukrayinskoyi movy [New Dictionary of Modern Ukrainian]. Kyiv: PP Golyaka V. M. 768 p. [in Ukrainian].

6. StandartISO/IEC 2382-1:1993(1993). Terminyiopredeleniya[Terms and Definitions]. Retrieved from: http://elib.sbras.ru:8080/jspui/bitstream/SBRAS/9193/1/ISOIEC_2382-1.pdf [in Russian].

7. Vynner, N. (1983) Kibernetyka, ili upravleniye i svyaz v zhivotnom i mashinye [Cybernetics, or control and communication in an animal and a machine]. Moskva: Nauka - Science. 344 p. [in Russian].

8. Shennon, K. (1963) Raboty po teorii ynformacii i kibernetike [Works on information theory and cybernetics]. Moskva: Izdatelstvo inostrannoj literatury - Publishing house of foreign literature. 830 p. [in Russian].

9. Sereda, S. G. (2011) Analiz ponyatiya «informaciya» metafory i traktovki [Analysis of the concept of "information" metaphor and interpretation]. Distancionoye i virtualnoye obucheniye - Distance and virtual education, 12, 130-149 [in Russian].

10. Sanochkin, V. V. (2001) Chto takoye informaciya [What is information]. Filosofskiye issledovaniya - Philosophical research, 3, 129-141 [in Russian].

11. Sokolov, A. V. (2011). Filosofiya informacii [Philosophy of information]. Chelyabinsk: Chelyabinskaya gosudarstvennaya akademiya kultury $\mathrm{i}$ iskusstva - Chelyabinsk State Academy of Culture and Arts. 455 p. [in Russian].

12. Glushkov, V. M. (1964). O kibernetike kak nauke [About cybernetics as a science]. Kibernetika, myshleniye, zhizn - Cybernetics, thinking and knowledge. Moskva. P. 53-62 [in Russian].

13. Zavizyena, N. S. (2010). Informacijna efektyvnist funkcionuvannya regionalnyx ekonomichnyx system [Information efficiency of functioning of regional economic system]. Retrieved from: http://www.nbuv.gov.ua/portal/Soc_Gum/Ekpr/2010_35/ Zm/8PDF.pdf. [in Ukrainian].

14. Kolin, K. K. (2010). Filosofskiye problemy informatiki [Philosophical problems of computer science]. Moskva: BINOM. 264 p. [in Russian].

15. Ursul, A. D. (2010). Priroda informacii : filosofskij ocherk [The nature of information: a philosophical essay]. Chelyabinsk. 231 p. [in Ukrainian].

16. Abdeev, R. F. (1994). Filosofiya informacionnoj civilizacii [Philosophy of information civilization]. Moskva: Vlados. 336 p. [in Russian].

17. Kolin, K. K. (2008). Struktura realnosti i fenomen informacii [The structure of reality and the phenomenon of information]. Otkrytoye obrazovaniye - Open education, 5 , 56-61 [in Ukrainian].

18. Anoxin, P. K. (1978). Filosofskiye aspekty teorii funkcionalnoj sistemy [Philosophical aspects of the theory of functional systems]. Moskva: Nauka - Science. 400 p. [in Russian]. 
19. Semanyuk, V. Z. (2018). Informacijna teoriya obliku v postindustrialnomu suspilstvi: monografiya [Information theory of accounting in post-industrial society: monograph]. Ternopil: TNEU. 392 p. [in Ukrainian].

20. Bard, A., Zoderkvist Ya. (2004). Netokratiya. Novaya pravyashhaya elita i zhizn posle kapitalizma [Netocracy. The new ruling elite and life after capitalism]. Spb. [b.y.]. 252 p. [in Ukrainian].

21. Xoruzhij, L. Y. (2004). Problemy teorii, metodologii, metodiki i organizacii upravlencheskogo ucheta v selskom xozyajstve [Problems of theory, methodology, methods and organization of management accounting in agriculture]. Moskva: Finansy i statistika - finance and statistics. 496 p. [in Russian].

22. Zaxarchishin, G. M. (2012). Integrovanyj rakurs problem innovacijnosti v informacijnomu suspilstvi. Aktualni problemy ekonomiky - Current economic problems, 12 (138), 10-15 [in Ukrainian].

23. Rodrigues, P. C., Silveira, F., Santos, B. M. and Molinar F. (2019). Analysis of publications of a scientific periodic: evaluation by the tool SPC. Independent Journal of Management \& Production (Special Edition IFLOG), 10 (4), 1213-1228. DOI: dx.doi.org/10.14807/ijmp.v10i4.755 [in English].

24. Semenyshena, N., Khorunzhak, N, Zadorozhnyi, Z.-M. (2020). The institutionalization of accounting: the impact of national standards on the development of economies. Independent Journal of Management \& Production, T. 11, No 8. P. 695-711. DOI: dx.doi.org/10.14807/ijmp.v11i8.1228 [in English].

25. Semenyshena, N., Khorunzhak, N. and Sadovska, I. (2020). Evaluation of the adaptability of scientific theories for the development of Accounting Institute. Intellectual Economics, Vol. 14, No 1, 113-129. DOI: https://doi.org/10.13165/IE-2014-1-07 [in English].

Статтю отримано 2 листопада 2020 p.

Article received November 2, 2020 